\title{
Recent progress in the treatment of non-systemic juvenile idiopathic arthritis
}

\author{
John M. Bridges ${ }^{1} \quad$ Elizabeth D. Mellins ${ }^{2} \quad$ Randy Q. Cron ${ }^{1 *}$ \\ ${ }^{1}$ Children's of Alabama/University of Alabama at Birmingham, Birmingham, Alabama, USA \\ ${ }^{2}$ Department of Pediatrics, Program in Immunology, Stanford University, Stanford, California, USA
}

\begin{abstract}
Juvenile idiopathic arthritis (JIA) is a chronic inflammatory disease affecting the joints and other organs that occurs in 1 in 1,000 children in the United States. Given the various categories of JIA, interpretation of the literature can be difficult. In this review, new developments in understanding non-systemic JIA and its treatment will be covered. Recent advances in the journey toward personalized treatment in JIA will be highlighted, including a review of currently available biologic modifiers. Uveitis and the temporomandibular joint will be discussed as particularly challenging treatment issues. Recent guideline updates and literatureguided treatment decisions will be reviewed.
\end{abstract}

\section{Keywords}

Juvenile idiopathic arthritis, uveitis, temporomandibular joint, biologic, DMARD

\section{Peer Review}

The peer reviewers who approve this article are:

1. Gerd Horneff, Department of Paediatric and Adolescents Medicine, Medical Faculty, University Hospital of Cologne, Cologne

Competing interests: No competing interests were disclosed

2. Christina Boros, Discipline of Paediatrics, University of Adelaide, Adelaide, Australia Department of Paediatric Rheumatology, Women's and Children's Hospital, Adelaide, Australia Competing interests: No competing interests were disclosed. 
*Corresponding author: Randy Q. Cron (rcron@peds.uab.edu)

Competing interests: The authors declare that they have no competing interests.

Grant information: The authors declare that no grants were involved in supporting this work.

Copyright: (C) 2021 Cron RQ et al. This is an open access article distributed under the terms of the Creative Commons Attribution License, which permits unrestricted use, distribution, and reproduction in any medium, provided the original work is properly cited.

How to cite this article: Bridges JM, Mellins ED and Cron RQ. Recent progress in the treatment of non-systemic juvenile idiopathic arthritis. Faculty Reviews 2021 10:(23) https://doi.org/10.12703/r/10-23

Published: 26 Feb 2021, Faculty Reviews 10:(23) https://doi.org/10.12703/r/10-23 


\section{Introduction}

Juvenile idiopathic arthritis (JIA) is a chronic inflammatory disease affecting the joints and other organs that occurs in 1 in 1,000 children in the United States ${ }^{1}$. Long-term complications of under-treated JIA include joint deformity, reduced quality of life, and significant disability ${ }^{2,3}$. The most widely used JIA classification, put forth by the International League of Associations for Rheumatology (ILAR), divides JIA into seven different groups based upon the number of joints affected and other accompanying features (see Table 1$)^{4}$. With this many categories, clinical interpretation of the research literature can be difficult. While most categories of JIA share similarities in disease presentation and pathophysiology, systemic JIA, psoriatic arthritis, and enthesitis-related arthritis are separate disease entities ${ }^{4}$. In this review, new developments in understanding non-systemic JIA and its treatment will be covered. We will discuss updates on understanding personalized diagnosis and management of JIA, current biologic treatment options, and recent guidelines and treatment decision research.

\section{The journey toward personalized treatment in JIA}

An individual-patient-level understanding of disease pathophysiology and ideal treatment regimen continues to be a compelling goal of current research efforts. In JIA, both a patient's underlying individual genetics and an understanding of the nature of a patient's microbiome seem to play important roles in the development of JIA, progression of the disease, and response to treatment.

The genetic underpinnings of JIA and their relationships to the phenotypic categories of the disease is a key component to understanding the pathophysiology and classification of JIA. Recent studies have identified divergent underlying genetics and microRNA patterns among JIA, its various categories, and healthy controls ${ }^{5,6}$. In a commentary, Nigrovic et al. advocated for a JIA classification scheme rooted in causal genetics and proposed four main clusters: rheumatoid factor seropositive, seronegative (with a distinct group that begins in early childhood), spondyloarthritis, and systemic arthritis (see Figure 1$)^{5,7,8}$. Classification of JIA categories continues to be a controversial topic ${ }^{9}$. Researchers also continue to gain a better genetic understanding of response to treatment in JIA patients. A recent study by Bašić et al. showed that polymorphisms in the catalase gene (responsible for decomposing hydrogen peroxide into water and oxygen) are associated with polyarticular JIA susceptibility and with response to tumor necrosis factor (TNF)

Table 1. International League of Associations for Rheumatology classification criteria for juvenile idiopathic arthritis.

\begin{tabular}{|c|c|c|}
\hline \multirow[t]{2}{*}{ Category } & Inclusion criteria & Exclusions \\
\hline & Arthritis & \\
\hline Systemic & $\begin{array}{l}\text { Fever at least } 2 \text { weeks; daily for at least } 3 \text { days } \\
\text { One or more of evanescent erythematous rash, lymphadenopathy, } \\
\text { hepatomegaly, splenomegaly, or serositis }\end{array}$ & $a, b, c, d$ \\
\hline Oligoarthritis & Arthritis in $1-4$ joints for the first 6 months & $a, b, c, d, e$ \\
\hline Polyarthritis (RF-) & $\begin{array}{l}\text { Arthritis affecting } 5 \text { or more joints during the first } 6 \text { months of disease } \\
\text { A test for RF (if performed) is negative }\end{array}$ & $a, b, c, d, e$ \\
\hline Polyarthritis $(\mathrm{RF}+)$ & $\begin{array}{l}\text { Arthritis affecting } 5 \text { or more joints during the first } 6 \text { months of disease } \\
2 \text { or more tests for RF at least } 3 \text { months apart during the first } 6 \text { months of disease } \\
\text { are positive }\end{array}$ & $a, b, c, d, e$ \\
\hline Psoriatic & $\begin{array}{l}\text { Arthritis and psoriasis; or } \\
\text { Arthritis accompanied by two of the following: dactylitis; nail pitting or } \\
\text { onycholysis; or psoriasis in a FDR }\end{array}$ & $b, c, d, e$ \\
\hline ERA & $\begin{array}{l}\text { Arthritis and enthesitis; or } \\
\text { Arthritis or enthesitis accompanied by at least } 2 \text { of the following: sacroiliac joint } \\
\text { tenderness and/or inflammatory lumbosacral pain; HLA-B27+; onset of arthritis } \\
\text { in a male over } 6 \text { years of age; AAU; history of ankylosing spondylitis, ERA, } \\
\text { sacroiliitis with inflammatory bowel disease, reactive arthritis, or AAU in a FDR }\end{array}$ & $\mathrm{a}, \mathrm{d}, \mathrm{e}$ \\
\hline Undifferentiated & Arthritis that fulfills criteria in no category or in 2 or more of the above categories. & \\
\hline
\end{tabular}




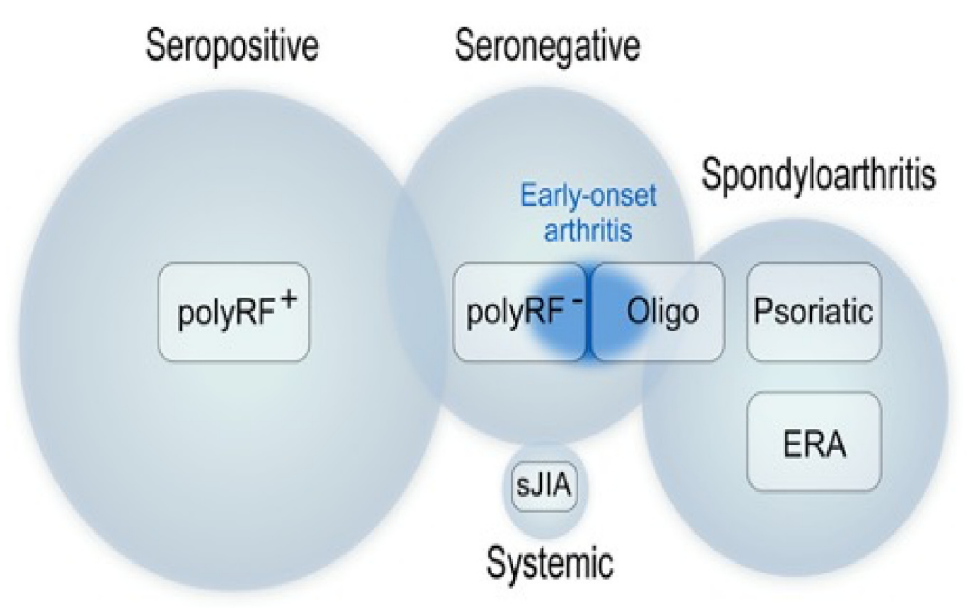

Figure 1. Proposed arthritis classification clusters based on current genetics studies. Boxes represent International League of Associations for Rheumatology (ILAR) categories of juvenile idiopathic arthritis (JIA). ERA, enthesitis-related arthritis; Oligo, oligoarticular JIA; polyRF+, polyarticular rheumatoid factor positive JIA; polyRF-, polyarticular rheumatoid factor negative JIA; SJIA, systemic JIA. Reused with permission from Nigrovic, Raychaudhuri, and Thompson?

inhibition therapy, suggesting an important role of oxidative stress in disease ${ }^{10}$. Knowing that leukemia patients can have altered responses to methotrexate based on SLCO1B1 allele type, Ramsey and colleagues showed that certain alleles of this gene were associated with decreased response to methotrexate in JIA patients, indicating a likely need for increased dosages in patients with these alleles compared to non-carriers ${ }^{11}$. Poppenberg et al. used machine learning of transcriptomes from peripheral blood mononuclear cells to predict disease activity in patients with JIA, forecasting future use of this approach to assess response to therapy ${ }^{12}$. Further research regarding the genetics of disease susceptibility and treatment response will likely move the field towards both biology-based classification and personalized treatment approaches ${ }^{13}$.

In addition to genetics, environmental factors contribute to JIA pathogenesis. Research continues to pursue an understanding of the relationship between the gut microbiome and JIA onset, activity, and response to therapy. Early life events that influence the composition of the microbiota (method of delivery at birth, feeding during infancy, home environment, and exposure to antibiotics ${ }^{14}$ ) significantly affect the mucosal barrier, nutritional absorption, and immune system development and ultimately also influence the risk of developing JIA. Along these lines, JIA patients have been reported to have abnormal microbiota (dysbiosis) compared to healthy individuals ${ }^{15}$. Van Dijkhuizen and colleagues used a multicenter prospective observational cohort study to illustrate gut dysbiosis in JIA patients (particularly in relation to increased levels of Erysipelotrichaceae and Faecalibacterium prausnitzii and decreased levels of Allobaculum $)^{16,17}$. However, relative abundance of individual pro- and anti-inflammatory strains of F. prausnitzii may be more relevant. A study by Grevich and colleagues suggested a link between oral dysbiosis and gingivitis and JIA, with JIA plaque microbiota analysis showing increased presence of Haemophilus and Kingella and decreased presence of Corynebacterium ${ }^{18}$. While studies continue to show correlations between dysbiosis, as well as decreased organismal diversity, and the development of JIA, it is still unclear if dysbiosis is simply a biomarker or if it actually contributes to the pathogenesis of JIA ${ }^{19,20}$. Nevertheless, JIA dysbiosis profiles seem to be unique and can be distinguished from healthy individuals and from other diseases using machine learning approaches ${ }^{21,22}$. Further study is needed to determine whether the microbiome is a useful therapeutic target in JIA and, if so, which approaches to alter the gut microbiome (fecal transplant, probiotics, or dietary alteration) are efficacious in $\mathrm{JIA}^{15}$.

Although an understanding of the underlying genetics and microbiome changes of an individual patient could be an important tool for informing treatment decision in the future, current practice does not take these into account when deciding optimal treatment courses for JIA patients.

\section{Treatment of JIA in the era of biologic modifiers}

Biologic disease modifiers have revolutionized the treatment of JIA patients over the past quarter century, and JIA patients have better disease outcomes with modern treatments than do adult rheumatoid arthritis (RA) patients ${ }^{23}$. The data showing that currently approved biologic therapy for JIA is efficacious continue to accumulate, with improved outcomes and decreased rates of need for orthopedic surgery and of complications like uveitis in modern era patients compared to those from the pre-biologic era $^{24-26}$. While TNF inhibition remains the mainstay of treatment, research continues to analyze and understand 
other targeted avenues, including interleukin-6 (IL-6) blockade, Janus kinase (JAK) pathway inhibition, T cell activation blockade, and anti-B cell therapy (see Table 2). Owing to clinical comfort and longer track record, most of these newer agents are still considered "second-line" behind TNF inhibitors, but data collection on their efficacy and safety continues.

Table 2. Biologic targeted treatment approaches to JIA.

\begin{tabular}{|c|c|c|c|c|c|c|}
\hline Drug & $\begin{array}{l}\text { Mechanism } \\
\text { of action }\end{array}$ & $\begin{array}{l}\text { FDA } \\
\text { indications in } \\
\text { children }\end{array}$ & $\begin{array}{l}\text { EMA } \\
\text { indications } \\
\text { in children }\end{array}$ & Dosing & $\begin{array}{l}\text { Adult } \\
\text { approval (FDA } \\
\text { \& EMA) }\end{array}$ & $\begin{array}{l}\text { Off label } \\
\text { evidence } \\
\text { (if not } \\
\text { FDA or EMA } \\
\text { approved in } \\
\text { children with } \\
\text { arthritis) }\end{array}$ \\
\hline Adalimumab & $\begin{array}{l}\text { TNF } \\
\text { inhibition }\end{array}$ & pJIA (>4yo) & $\begin{array}{l}\text { PJIA ( } \geq 2 \text { yo) } \\
\text { ERA-JIA } \\
\text { ( } \geq 6 \text { yo) } \\
\text { PP ( } \geq 4 \text { yo) } \\
\text { CD ( } \geq 6 \text { yo) } \\
\text { NIU ( } \geq 2 \text { yo }) \\
\text { HS ( } \geq 12 \text { yo) }\end{array}$ & SC every other week & $\begin{array}{l}\text { RA } \\
\text { PsA } \\
\text { AS } \\
\text { PP } \\
\text { CD } \\
\text { UC (EMA only) } \\
\text { HS (EMA only) } \\
\text { NIU (EMA only) }\end{array}$ & \\
\hline Etanercept & $\begin{array}{l}\text { TNF } \\
\text { inhibition }\end{array}$ & $\begin{array}{l}\text { pJIA ( } \geq 2 y o) \\
\operatorname{PP}(\geq 4 y o)\end{array}$ & $\begin{array}{l}\text { ERA-JIA } \\
(\geq 12 \text { yo) } \\
\text { EO JIA ( } \geq 2 \text { yo) } \\
\text { PJIA ( } \geq 2 \text { yo) } \\
P S J I A ~(\geq 12 \text { yo) } \\
P P(\geq 6 \text { yo })\end{array}$ & 1-2 times weekly SC & $\begin{array}{l}\text { RA } \\
\text { PsA } \\
\text { AS } \\
\text { PP }\end{array}$ & \\
\hline Infliximab & $\begin{array}{l}\text { TNF } \\
\text { inhibition }\end{array}$ & $\begin{array}{l}\text { UC ( } \geq 6 \text { yо }) \\
C D(\geq 6 y o)\end{array}$ & $\begin{array}{l}\text { UC ( } \geq 6 \text { yo }) \\
C D(\geq 6 \text { yo })\end{array}$ & $\begin{array}{l}\text { IV every 6-8 weeks } \\
\text { (after loading doses) }\end{array}$ & $\begin{array}{l}\text { RA } \\
\text { PsA } \\
\text { AS } \\
\text { PP } \\
\text { UC } \\
\text { CD }\end{array}$ & 27,28 \\
\hline Golimumab & $\begin{array}{l}\text { TNF } \\
\text { inhibition }\end{array}$ & $\begin{array}{l}\text { pJIA ( } \geq 2 y o) \\
\text { PsJIA ( } \geq 2 \text { yo) }\end{array}$ & pJIA ( $\geq 2 y o)$ & $\begin{array}{l}\text { SC injection monthly or } \\
\text { IV every } 8 \text { weeks (after } \\
\text { loading doses) }\end{array}$ & $\begin{array}{l}\text { RA } \\
\text { PsA } \\
\text { AS } \\
\text { UC }\end{array}$ & \\
\hline $\begin{array}{l}\text { Certolizumab } \\
\text { pegol }\end{array}$ & $\begin{array}{l}\text { TNF } \\
\text { inhibition }\end{array}$ & None & None & $\begin{array}{l}\text { SC injections monthly } \\
\text { (after loading doses) }\end{array}$ & $\begin{array}{l}\text { RA } \\
\text { PSA } \\
\text { AS } \\
\text { PP } \\
\text { CD (FDA only) }\end{array}$ & \\
\hline Rituximab & B cell depletion & None & None & $\begin{array}{l}2 \text { IV infusions every } \\
16-24 \text { weeks }\end{array}$ & $\begin{array}{l}\text { RA } \\
\text { GPA } \\
\text { MPA } \\
\text { NHL } \\
\text { CML } \\
\text { PV }\end{array}$ & $29-31,32$ \\
\hline Anakinra & IL-1 blockade & CAPS & $\begin{array}{l}\text { SJIA ( } \geq 8 \mathrm{mo}) \\
\text { CAPS }(\geq 8 \mathrm{mo}) \\
\text { FMF }(\geq 8 \mathrm{mo})\end{array}$ & SC daily & $\begin{array}{l}\text { RA } \\
\text { AOSD (EMA } \\
\text { only) }\end{array}$ & 33 \\
\hline
\end{tabular}




\begin{tabular}{|c|c|c|c|c|c|c|}
\hline Drug & $\begin{array}{l}\text { Mechanism } \\
\text { of action }\end{array}$ & $\begin{array}{l}\text { FDA } \\
\text { indications in } \\
\text { children }\end{array}$ & $\begin{array}{l}\text { EMA } \\
\text { indications } \\
\text { in children }\end{array}$ & Dosing & $\begin{array}{l}\text { Adult } \\
\text { approval (FDA } \\
\text { \& EMA) }\end{array}$ & $\begin{array}{l}\text { Off label } \\
\text { evidence } \\
\text { (if not } \\
\text { FDA or EMA } \\
\text { approved in } \\
\text { children with } \\
\text { arthritis) }\end{array}$ \\
\hline \multirow[t]{2}{*}{ Canakinumab } & IL-1 blockade & $\begin{array}{l}\text { SJIA ( } \geq 2 y o) \\
\text { CAPS ( } \geq 4 y o) \\
\text { TRAPS } \\
\text { Hyper IgD } \\
\text { FMF }\end{array}$ & $\begin{array}{l}\text { sJIA ( } \geq 2 \text { yo) } \\
\text { CAPS ( } \geq 2 \text { yo) } \\
\text { TRAPS ( } \geq 2 \text { yo) } \\
\text { Hyper IgD } \\
(\geq 2 \text { yo) }\end{array}$ & SC every 4 weeks & $\begin{array}{l}\text { Gout (EMA } \\
\text { only) }\end{array}$ & \\
\hline & & & FMF (>2yo) & & & \\
\hline Tocilizumab & IL-6 blockade & $\begin{array}{l}\text { pJIA ( } \geq 2 y o) \\
\text { SJIA ( } \geq 2 \text { yo) CRS } \\
(\geq 2 y o)\end{array}$ & $\begin{array}{l}\text { pJIA ( } \geq 2 \text { yo) } \\
\text { eoJIA ( } \geq 2 \text { yo) } \\
\text { sJIA ( } \geq 1 \text { yo) } \\
\text { CRS ( } \geq 2 \text { yo) }\end{array}$ & IV or SC every 4 weeks & RA GCA & \\
\hline Sarilumab & IL-6 blockade & None & None & SC every 2 weeks & RA & \\
\hline Secukinumab & IL-17 blockade & None & $\mathrm{PP}(\geq 2 \mathrm{yo})$ & $\begin{array}{l}\text { SC every } 4 \text { weeks (with } \\
\text { or without loading dose) }\end{array}$ & $\begin{array}{l}\text { PP } \\
\text { PsA } \\
\text { AS }\end{array}$ & 34 \\
\hline Ixekizumab & IL-17 blockade & None & $\operatorname{PP}(\geq 6 y o)$ & $\begin{array}{l}\text { SC every } 4 \text { weeks (after } \\
\text { loading dose) }\end{array}$ & $\begin{array}{l}\text { PsA } \\
\text { AS } \\
\text { PP }\end{array}$ & \\
\hline Brodalumab & IL-17 blockade & None & None & $\begin{array}{l}\text { SC every } 2 \text { weeks (after } \\
\text { loading dose) }\end{array}$ & PP & \\
\hline Abatacept & $\begin{array}{l}\text { T cell } \\
\text { deactivation }\end{array}$ & pJIA ( $\geq 2 y o)$ & pJIA ( $\geq 2$ yo) & $\begin{array}{l}\text { IV every } 4 \text { weeks (after } \\
\text { loading dose) }\end{array}$ & RA PsA & \\
\hline Ustekinumab & $\begin{array}{l}\text { IL-12 \& IL-23 } \\
\text { blockade }\end{array}$ & $\mathrm{PP}(\geq 12 \mathrm{yo})$ & $\mathrm{PP}(\geq 6$ уо $)$ & $\begin{array}{l}\text { SC every } 12 \text { weeks } \\
\text { (after loading, which } \\
\text { can be SC or IV) }\end{array}$ & $\begin{array}{l}\text { PsA } \\
\text { PP } \\
\text { CD } \\
\text { UC }\end{array}$ & 35,36 \\
\hline
\end{tabular}

AOSD, adult-onset Still disease; AS, ankylosing spondylitis; CAPS, cryopyrin-associated periodic syndromes; CD, Crohn's disease; CML, chronic myelogenous leukemia; EMA, European Medicines Agency; eoJIA, extended oligoarticular juvenile idiopathic arthritis; ERA-JIA, enthesitis-related arthritis juvenile idiopathic arthritis; FDA, Food and Drug Administration (United States); FMF, familial Mediterranean fever; GCA, giant cell arteritis GPA, granulomatosis with polyangiitis; HS, hidradenitis suppurativa; IL, interleukin; IV, intravenous; mo, months old; MPA, microscopic polyangiitis NHL, non-Hodgkin lymphoma; NIU, non-infectious uveitis; pJIA, polyarticular juvenile idiopathic arthritis; PP, plaque psoriasis; PsA, psoriatic arthritis; PSJIA, psoriatic juvenile idiopathic arthritis; PV, pemphigus vulgaris; RA, rheumatoid arthritis; SC, subcutaneous; TNF, tumor necrosis factor; TRAPS, tumor necrosis factor receptor associated periodic syndrome; UC, ulcerative colitis; yo, years old.

\section{Treatment agents}

TNF inhibitors are a reliable way to induce remission in non-systemic JIA patients and are the backbone of current JIA treatment regimens ${ }^{37,38}$. TNF inhibitors are divided into two classes: monoclonal antibodies against TNF (infliximab, adalimumab, certolizumab pegol, and golimumab) and a receptor fusion protein (etanercept). The monoclonal antibodies against TNF provide better treatment for granulomatous conditions, including inflammatory bowel disease and uveitis. There are several recent publications addressing the benefits of TNF inhibitors in treating JIA. TNF inhibitors are most effective when given early on in disease course ${ }^{39}$. Standard dosing regimens are occasionally adjusted based on clinical changes, but therapeutic drug monitoring is not yet a component of routine clinical management ${ }^{40}$. Immunogenicity (and thereby decreased efficacy) can occur with the use of TNF inhibitors and is diminished by concomitant methotrexate use in adult patients with RA; this has not been clearly shown in JIA, and clinical monitoring of anti-drug antibodies is not current standard of practice in pediatric rheumatology care unless decreased clinically efficacy is noticed ${ }^{41-44}$. A common concern with patients on TNF inhibitors revolves around the long-term effects of drug therapy, including infection risk, malignancy risk, and adverse drug effects. Large registry studies and systematic reviews continue to find that, overall, TNF inhibition is safe, effective, and well tolerated $^{45-51}$. 
Another targetable pro-inflammatory cytokine for children with arthritis is IL-6. Recent updates have been published detailing the role of IL-6 blockade in treating JIA. Tocilizumab is an antibody against the IL- 6 receptor that can be used as an alternative treatment for JIA and is available in intravenous and subcutaneous forms. It can be particularly effective for previously treatment-resistant patients ${ }^{52}$ but has the potential adverse effects of cytopenias and elevated transaminases ${ }^{47,53}$ and similar infection rates to TNF inhibition ${ }^{24}$. Significant adverse events with tocilizumab are more likely to occur with concomitant immunosuppression ${ }^{54}$. Tocilizumab continues to be an option in the management of JIA, particularly in previously treatment-resistant patients, but regular monitoring for adverse effects is necessary ${ }^{55}$.

Beyond cytokine blockade, disruption of T cell co-stimulation is an alternative approach to treating JIA. Abatacept (CTLA-4-Ig) interferes with $\mathrm{T}$ cell activation and is a newer treatment option for patients with JIA. Abatacept is available in both intravenous and subcutaneous forms, providing options for optimal treatment plans for patients. Research continues to pursue an understanding of abatacept's efficacy, adverse event profile, and overall effect on the immune system. Open label trials and systematic reviews consistently show a favorable safety profile ${ }^{24,46,54,56}$. Given abatacept's effects on $\mathrm{T}$ cells, there has been concern over the implications of this therapy on vaccine-induced immunity; however, a substudy of 222 patients with polyarticular JIA receiving subcutaneous abatacept showed maintenance of effective diphtheria and tetanus vaccination protection ${ }^{57}$. Abatacept remains an option for biologic treatment in patients with JIA, including those with uveitis.

Clinicians and researchers continue to show interest in using other biologic modifiers for the treatment of JIA, particularly those approved for adult RA. Agents of interest include those blocking IL-1 (anakinra and canakinumab), IL-17 (secukinumab and ixekizumab), and IL-12/23 (ustekinumab) as well as Janus kinase inhibitors (tofacitinib, baricitinib, upadacitinib, and filgotinib). Tofacitinib has recently been approved by the FDA for polyarticular JIA and is available in an oral solution ${ }^{58}$. Rituximab, a monoclonal antibody targeting $\mathrm{B}$ cells, is not licensed specifically for JIA, but it can still be a treatment option for these patients, with an effective response and a low rate of adverse events ${ }^{35,54,59-61}$.

Patients treated with biologic modifiers have better disease outcomes than patients in the pre-biologic era, with lower rates of complications overall. The data showing that currently approved biologic therapy for JIA is efficacious continue to accumulate $^{24}$. Berthold et al. collected JIA cases between 2002 and 2010 in part of Sweden and noted the need for orthopedic surgery and the presence of uveitis were diminished in comparison to studies of patients diagnosed over 20 years ago. However, active disease was still experienced by these patients more than $50 \%$ of the time, indicating persistent treatment challenges despite the development of biologic therapy ${ }^{25}$. Giancane et al. compared two groups of JIA patients, methotrexate era (disease presentation before 2000) versus biologic era (disease presentation after 2000), using a cross-sectional assessment to assess disease activity and joint damage and found significant improvement in outcomes in the biologic-era patients compared to the methotrexate-era patients ${ }^{26}$. Arnstad et al. used the Nordic cohort to show that early self-reported disease-related pain predicted persistent pain and unfavorable long-term disease outcomes ${ }^{62}$. Henrey et al. employed a fine-tuned Nordic model to predict non-achievement of remission and severe disease course in a cohort of Canadian JIA patients, illustrating the potential utility of this model in outcomes research ${ }^{63}$. TNF inhibitors are the backbone of biologic therapy with other available options, including abatacept and tocilizumab, while data continue to be collected on the use of other biologic agents for the treatment of JIA $27-33,35,64,65$. Biologic treatments have revolutionized care for JIA patients; however, there is still an ongoing need for new medications to treat JIA, particularly jaw arthritis ${ }^{65,66}$.

\section{Temporomandibular involvement}

The temporomandibular joint (TMJ) continues to be a difficult-to-treat and common site of involvement for juvenile arthritis, affecting mandibular growth and development and causing potential deformity and adverse quality of life outcomes ${ }^{67-70}$. A Danish cohort study showed a cumulative incidence of orofacial symptoms in JIA approaching $50 \%$ at 5 years after JIA onset $^{71}$. The ideal methods for identifying, imaging, and scoring TMJ dysfunction, as well as its treatment, continue to be topics of much discussion, but magnetic resonance imaging with contrast of the TMJ read by a radiologist with experience in TMJ arthritis imaging is the current standard of care c2-77. $^{72}$. Standardization of measurement of TMJ involvement has been developed by an international working group, and there is also an effort to identify the ideal timing of potential surgical intervention $^{78-81}$. There is evidence to support the notion that treatment of arthritis with systemic therapy is also beneficial for the TMJ; however, optimal treatment of TMJ arthritis in children with JIA remains a significant challenge ${ }^{82,83}$.

\section{Treatment guidelines and decision-making}

In 2019, the American College of Rheumatology (ACR) and Arthritis Foundation updated treatment guidelines for JIA from their previous 2011 guidelines, defining patient populations by clinical phenotypes rather than ILAR categories, in line with current understanding of biology and treatment response. Major changes included removal of NSAID monotherapy as first-line treatment for polyarthritis. In fact, in the presence of certain risk factors (joint damage or positive anti-cyclic citrullinated peptide antibodies), first-line treatment for polyarthritis can be biologic therapy. Given mostly equivalent safety and efficacy data between biologic agents (and overall lack of head-to-head comparison studies), specific biologic modifiers are only recommended in particular scenarios: TNF inhibitors are specifically recommended for sacroiliitis, and rituximab is recommended only after TNF inhibition, abatacept, and tocilizumab have been tried. The overall quantity and quality of evidence continues to be low, and shared decision making among clinicians, patients, and parents continues to be recommended. The guidelines make no recommendations regarding 
agents for JAK inhibition, IL-17 blockade, and IL-12/23 inhibition but point towards studies underway to help determine the future role for these therapies in JIA treatment ${ }^{38}$.

In addition to treating the arthritis associated with JIA, the ACR and Arthritis Foundation produced a 2019 guideline for screening, monitoring, and treating JIA-associated uveitis. The British Society for Pediatric and Adolescent Rheumatology, in coordination with the Royal College of Ophthalmologists, has also produced a similar guideline ${ }^{84}$. These guidelines were limited by lack of high-quality evidence and few randomized controlled trials, instead relying mainly upon expert opinion. Regular screening for uveitis is emphasized in JIA patients as well as regular monitoring of patients with previously diagnosed uveitis, particularly around times of transitions in therapy. Methotrexate, adalimumab, and infliximab are recommended when systemic treatment is needed for uveitis ${ }^{85}$, and a multicenter, double-blind, randomized, placebo-controlled trial has demonstrated efficacy of adalimumab with methotrexate compared to methotrexate alone in the treatment of JIA-associated uveitis $^{86}$. In addition to anti-TNF monoclonal antibodies, tocilizumab, rituximab, and abatacept may all have roles in treating refractory uveitis in the setting of JIA.

Skillful JIA management relies upon accurate assessment of disease severity, possibility of achieving remission, likelihood of relapse, and overall treatment efficacy to inform strategic treatment decisions. Accurate assessment of clinical disease activity involves a combination of clinician assessment, patient assessment, and laboratory criteria. Widely used current clinical assessment criteria are not perfect tools, overlooking some aspects of disease and overemphasizing other factors ${ }^{87}$. Clinical, serologic, and imaging predictors of disease remission are still elusive, leaving clinical expertise and experience as the main compass for navigating treatment decisions prior to achievement of clinical remission ${ }^{88-90}$. Numerous models have been developed for the prediction of disease severity, risk of non-achievement of remission, and risk of relapse; however, JIA category continues to be the strongest predictor of remission, with highest rates of remission in persistent oligoarticular JIA and lowest rates of remission in rheumatoid factor-positive polyarticular JIA ${ }^{62,63,91-97}$. Utilization of these tools to drive treatment decisions is helpful, but patient involvement in shared decision making is also an important component in treatment ${ }^{98}$. Data from multiple registries suggest that a "window of opportunity" for early treatment with disease-modifying therapies is associated with better disease control and outcomes, underscoring the importance of early aggressive therapy at time of diagnosis ${ }^{99}$. With the availability of numerous effective therapies, the concept of treat-to-target (with target being remission or low disease activity) is an effective guide to decision making in the care of JIA patients ${ }^{100-102}$.

\section{Conclusion}

Research continues to push JIA treatment towards the era of therapy personalization with better understandings of underlying genetics and the role of the microbiome. Treatment increasingly relies on biologic modifier therapy, and patient outcomes continue to improve with aggressive therapy. Uveitis and TMJ involvement continue to complicate JIA treatment decisions, and guidelines have yet to include less common biologic therapies for refractory cases. Disease category continues to be the best predictor for remission, but biomarker and polymorphism data hold promise as possibilities for more personalized approaches to JIA treatment in the future.

\section{Author contributions}

John M. Bridges undertook investigation, visualization, and preparation of the original draft. Elizabeth D. Mellins and Randy Q. Cron undertook the conceptualization, supervision, and reviewing and editing of the manuscript.
1. Helmick CG, Felson DT, Lawrence RC, et al.: Estimates of the prevalence of arthritis and other rheumatic conditions in the United States. Part I. Arthritis Rheum. 2008; 58(1): 15-25. PubMed Abstract | Publisher Full Text

2. Guzman J, Oen K, Tucker LB, et al:: The outcomes of juvenile idiopathic arthritis in children managed with contemporary treatments: Results from the ReACCh-Out cohort. Ann Rheum Dis. 2015; 74(10): 1854-60. PubMed Abstract | Publisher Full Text

3. Guzman J, Henrey A, Loughin T, et al:: Predicting Which Children with Juvenile Idiopathic Arthritis Will Have a Severe Disease Course: Results from the ReACCh-Out Cohort. J Rheumatol. 2017; 44(2): 230-40. PubMed Abstract | Publisher Full Text

4. Petty RE, Southwood TR, Manners P, et al:: International League of Associations for Rheumatology classification of juvenile idiopathic arthritis: Second revision, Edmonton, 2001. J Rheumatol. 2004; 31(2): 390-2. PubMed Abstract

5. Nigrovic PA, Martínez-Bonet M, Thompson SD: Implications of juvenile idiopathic arthritis genetic risk variants for disease pathogenesis and classification.
Curr Opin Rheumatol. 2019; 31(5): 401-10. PubMed Abstract | Publisher Full Text | Free Full Text

6. Nziza N, Duroux-Richard I, Apparailly F: MicroRNAs in juvenile idiopathic arthritis: Can we learn more about pathophysiological mechanisms? Autoimmun Rev. 2019; 18(8): 796-804. PubMed Abstract | Publisher Full Text

7. Nigrovic PA, Raychaudhuri S, Thompson SD: Review: Genetics and the Classification of Arthritis in Adults and Children. Arthritis Rheumatol. 2018; 70(1): 7-17.

PubMed Abstract | Publisher Full Text | Free Full Text | Faculty Opinions Recommendation

8. Beukelman T, Nigrovic PA: Juvenile Idiopathic Arthritis: An Idea Whose Time Has Gone? J Rheumatol. 2019; 46(2): 124-6. PubMed Abstract | Publisher Full Text

9. Stoll ML, Mellins ED: Psoriatic arthritis in childhood: A commentary on the controversy. Clin Immunol. 2020; 214: 108396.

PubMed Abstract | Publisher Full Text 
10. Bašić J, Vojinović J, Jevtović-Stoimenov T, et al:: The association of CAT-262C/T polymorphism with catalase activity and treatment response in juvenile idiopathic arthritis. Rheumatol Int. 2019; 39(3): 551-9.

PubMed Abstract | Publisher Full Text | Faculty Opinions Recommendation

11. Ramsey LB, Moncrieffe H, Smith CN, et al.: Association of SLCO1B1 *14 Allele with Poor Response to Methotrexate in Juvenile Idiopathic Arthritis Patients. ACR Open Rheumatol. 2019; 1(1): 58-62. PubMed Abstract | Publisher Full Text | Free Full Text | Faculty Opinions Recommendation

12. Poppenberg KE, Jiang K, Li L, et al.: The feasibility of developing biomarkers from peripheral blood mononuclear cell RNAseq data in children with juvenile idiopathic arthritis using machine learning approaches. Arthritis Res Ther. 2019; 21(1): 230.

PubMed Abstract | Publisher Full Text | Free Full Text | Faculty Opinions Recommendation

13. Rezaei E, Hogan D, Trost B, et al:: Associations of clinical and inflammatory biomarker clusters with juvenile idiopathic arthritis categories. Rheumatology (Oxford). 2020; 59(5): 1066-75.

PubMed Abstract | Publisher Full Text

14. Horton DB, Scott FI, Haynes K, et al.: Antibiotic Exposure and Juvenile Idiopathic Arthritis: A Case-Control Study. Pediatrics. 2015; 136(2): e333-43. PubMed Abstract | Publisher Full Text | Free Full Text

15. Arvonen $M$, Vänni $P$, Sarangi $A N$, et al:: Microbial orchestra in juvenile idiopathic arthritis: Sounds of disarray? Immunol Rev. 2020; 294(1): 9-26. PubMed Abstract | Publisher Full Text

16. Vvan Dijkhuizen EHP, Del Chierico F, Malattia C, et al:: Microbiome Analytics of the Gut Microbiota in Patients With Juvenile Idiopathic Arthritis: A Longitudinal Observational Cohort Study. Arthritis Rheumatol. 2019; 71(6): 1000-10.

PubMed Abstract | Publisher Full Text | Free Full Text | Faculty Opinions Recommendation

17. Stoll ML, Weiss PF, Weiss JE, et al:: Age and fecal microbial strain-specific differences in patients with spondyloarthritis. Arthritis Res Ther. 2018; 20(1): 14. PubMed Abstract | Publisher Full Text | Free Full Text

18. Grevich S, Lee P, Leroux B, et al:: Oral health and plaque microbial profile in juvenile idiopathic arthritis. Pediatr Rheumatol Online J. 2019; 17(1): 81. PubMed Abstract | Publisher Full Text | Free Full Text | Faculty Opinions Recommendation

19. Horton DB: Juvenile Idiopathic Arthritis and the Gut Microbiome: More Clues, More Questions. Arthritis Rheumatol. 2019; 71(6): 842-5. PubMed Abstract | Publisher Full Text | Free Full Text

20. Stoll ML, Cron RQ: The microbiota in pediatric rheumatic disease: Epiphenomenon or therapeutic target? Curr Opin Rheumatol. 2016; 28(5): 537-43.

PubMed Abstract | Publisher Full Text | Free Full Text

21. Bang S, Yoo D, Kim SJ: Establishment and evaluation of prediction mode for multiple disease classification based on gut microbial data. Sci Rep. 2019 9(1): 10189 .

9(1): 10189.
PubMed Abstract | Publisher Full Text | Free Full Text | Faculty Opinions Recommendation

22. de Filippo C, di Paola M, Giani T, et al:: Gut microbiota in children and altered profiles in juvenile idiopathic arthritis. J Autoimmun. 2019; 98: 1-12. PubMed Abstract | Publisher Full Text

23. Matsumoto T, Matsui T, Hirano F, et al.: Disease activity, treatment and longterm prognosis of adult juvenile idiopathic arthritis patients compared with rheumatoid arthritis patients. Mod Rheumatol. 2020; 30(1): 78-84. PubMed Abstract | Publisher Full Text | Faculty Opinions Recommendation

24. Diener C, Horneff G: Comparison of adverse events of biologicals for treatment of juvenile idiopathic arthritis: A systematic review. Expert Opin Drug Saf. 2019; 18(8): 719-32. PubMed Abstract | Publisher Full Text | Faculty Opinions Recommendation

25. Berthold E, Månsson B, Kahn R: Outcome in juvenile idiopathic arthritis: A population-based study from Sweden. Arthritis Res Ther. 2019; 21(1): 218. PubMed Abstract | Publisher Full Text | Free Full Text | Faculty Opinions Recommendation

26. Ciancane G, Muratore V, Marzetti V, et al.: Disease activity and damage in juvenile idiopathic arthritis: Methotrexate era versus biologic era. Arthritis Res Ther. 2019; 21(1): 168.

PubMed Abstract | Publisher Full Text | Free Full Text |

Faculty Opinions Recommendation

27. Lamot L, Bukovac LT, Vidovic M, et al:: The 'head-to-head' comparison of etanercept and infliximab in treating children with juvenile idiopathic arthritis. Clin Exp Rheumatol. 2011; 29(1): 131-9. PubMed Abstract

28. Lahdenne $\mathrm{P}$, Vähäsalo $\mathrm{P}$, Honkanen V: Infliximab or etanercept in the treatment of children with refractory juvenile idiopathic arthritis: An open label study. Ann Rheum Dis. 2003; 62(3): 245-7. PubMed Abstract | Publisher Full Text | Free Full Tex
29. Jansson AF, Sengler C, Kuemmerle-Deschner J, et al:: B cell depletion for autoimmune diseases in paediatric patients. Clin Rheumatol. 2011; 30(1): 87-97.

PubMed Abstract | Publisher Full Text

30. El-Hallak M, Binstadt BA, Leichtner AM, et al.: Clinical effects and safety of rituximab for treatment of refractory pediatric autoimmune diseases. $J$ Pediatr. 2007; 150(4): 376-82.

PubMed Abstract | Publisher Full Text

31. Kuek A, Hazleman BL, Gaston JH, et al.: Successful treatment of refractory polyarticular juvenile idiopathic arthritis with rituximab. Rheumatology (Oxford). 2006; 45(11): 1448-9.

PubMed Abstract | Publisher Full Text

32. Alexeeva El, Valieva SI, Bzarova TM, et al:: Efficacy and safety of repeat courses of rituximab treatment in patients with severe refractory juvenile idiopathic arthritis. Clin Rheumatol. 2011; 30(9): 1163-72.

PubMed Abstract | Publisher Full Text

33. Ilowite N, Porras O, Reiff A, et al:: Anakinra in the treatment of polyarticularcourse juvenile rheumatoid arthritis: Safety and preliminary efficacy results of a randomized multicenter study. Clin Rheumatol. 2009; 28(2): 129-37. PubMed Abstract | Publisher Full Text

34. Wells LE, Evans T, Hilton R, et al:: Use of secukinumab in a pediatric patient leads to significant improvement in nail psoriasis and psoriatic arthritis. Pediatr Dermatol. 2019; 36(3): 384-385. PubMed Abstract | Publisher Full Text

35. Mannion ML, McAllister L, Cron RQ, et al.: Ustekinumab as a Therapeutic Option for Children With Refractory Enthesitis-Related Arthritis. J Clin Rheumatol. 2016; 22(5): 282-4

PubMed Abstract | Publisher Full Text

36. Kellen R, Silverberg NB, Lebwohl M: Efficacy and safety of ustekinumab in adolescents. Pediatric Health Med Ther. 2016; 7: 109-20. PubMed Abstract | Publisher Full Text | Free Full Text

37. Slexeeva E, Dvoryakovskaya T, Denisova R, et al.: Dynamics of concomitant therapy in children with juvenile idiopathic arthritis treated with etanercept and methotrexate. Pediatr Neonatol. 2019; 60(5): 549-55. PubMed Abstract | Publisher Full Text | Faculty Opinions Recommendation

38. Ringold S, Angeles-Han ST, Beukelman T, et al.: 2019 American College of Rheumatology/Arthritis Foundation Guideline for the Treatment of Juvenile Idiopathic Arthritis: Therapeutic Approaches for Non-Systemic Polyarthritis, Sacroiliitis, and Enthesitis. Arthritis Care Res (Hoboken). 2019; 71(6): 717-34. PubMed Abstract | Publisher Full Text | Free Full Text

39. Liu DW, Chen JJ, Tang XM, et al.: Infliximab therapy and outcomes in patients with polyarticular juvenile idiopathic arthritis: A single-center study in China. World J Pediatr. 2020; 16(1): 68-73. PubMed Abstract | Publisher Full Text | Faculty Opinions Recommendation

40. Verstegen RHJ, McMillan R, Feldman BM, et al:: Towards therapeutic drug monitoring of TNF inhibitors for children with juvenile idiopathic arthritis: A scoping review. Rheumatology (Oxford). 2020; 59(2): 386-97. PubMed Abstract | Publisher Full Text

41. Bader-Meunier B, Krzysiek R, Lemelle I, et al.: Etanercept concentration and immunogenicity do not influence the response to Etanercept in patients with juvenile idiopathic arthritis. Semin Arthritis Rheum. 2019; 48(6): 1014-8. PubMed Abstract | Publisher Full Text

42. Doeleman MJH, van Maarseveen EM, Swart JF: Immunogenicity of biologic agents in juvenile idiopathic arthritis: A systematic review and meta-analysis. Rheumatology (Oxford). 2019; 58(10): 1839-49. PubMed Abstract | Publisher Full Text | Free Full Text

43. Atiqi S, Hooijberg F, Loeff FC, et al:: Immunogenicity of TNF-Inhibitors. Front Immunol. 2020; 11: 312

PubMed Abstract | Publisher Full Text | Free Full Text

44. Krieckaert CL, Nurmohamed MT, Wolbink GJ: Methotrexate reduces immunogenicity in adalimumab treated rheumatoid arthritis patients in a dose dependent manner. Ann Rheum Dis. 2012; 71(11): 1914-5. PubMed Abstract | Publisher Full Text

45. Nagy A, Mátrai $P$, Hegyi $P$, et al.: The effects of TNF-alpha inhibitor therapy on the incidence of infection in JIA children: A meta-analysis. Pediatr Rheumatol Online J. 2019; 17(1): 4

PubMed Abstract | Publisher Full Text | Free Full Text

46. Dumaine C, Bekkar S, Belot A, et al:: Infectious adverse events in children with Juvenile Idiopathic Arthritis treated with Biological Agents in a real-life setting: Data from the JIRcohorte. Joint Bone Spine. 2020; 87(1): 49-55. PubMed Abstract | Publisher Full Text | Faculty Opinions Recommendation

47. Klein A, Becker I, Minden K, et al.: Biologic Therapies in Polyarticular Juvenile Idiopathic Arthritis. Comparison of Long-Term Safety Data from the German BIKER Registry. ACR Open Rheumatol. 2020; 2(1): 37-47. PubMed Abstract | Publisher Full Text | Free Full Text | Faculty Opinions Recommendation

48. Klein A, Becker I, Minden K, et al: Adalimumab versus adalimumab and methotrexate for the treatment of juvenile idiopathic arthritis: Long-term data from the German BIKER registry. Scand J Rheumatol. 2019; 48(2): 95-104. PubMed Abstract | Publisher Full Text 
49. Foeldvari I, Constantin T, Vojinovi J, et al:: Etanercept treatment for extended oligoarticular juvenile idiopathic arthritis, enthesitis-related arthritis, or psoriatic arthritis: 6-year efficacy and safety data from an open-label trial. Arthritis Res Ther. 2019; 21(1): 125 .

PubMed Abstract | Publisher Full Text

50. Aeschlimann FA, Chong SL, Lyons TW, et al:: Risk of Serious Infections Associated with Biologic Agents in Juvenile Idiopathic Arthritis: A Systematic Review and Meta-Analyses. J Pediatr. 2019; 204: 162-171.e3. PubMed Abstract | Publisher Full Text

51. Beukelman $\mathrm{T}$, Xie F, Chen L, et al.: Rates of hospitalized bacterial infection associated with juvenile idiopathic arthritis and its treatment. Arthritis Rheum. 2012; 64(8): 2773-80.

PubMed Abstract | Publisher Full Text | Free Full Text

52. Grönlund MM, Remes-Pakarinen $\mathrm{T}$, Kröger L, et al.: Efficacy and safety of tocilizumab in a real-life observational cohort of patients with polyarticular juvenile idiopathic arthritis. Rheumatology (Oxford). 2020; 59(4): 732-741. PubMed Abstract | Publisher Full Text | Faculty Opinions Recommendation

53. Pardeo M, Wang J, Ruperto N, et al:: Neutropenia During Tocilizumab Treatment Is Not Associated with Infection Risk in Systemic or Polyarticular-course Juvenile Idiopathic Arthritis. J Rheumatol. 2019; 46(9): 1117-1126. PubMed Abstract | Publisher Full Text

54. Cabrera N, Lega JC, Kassai B, et al.: Safety of biological agents in paediatric rheumatic diseases: A real-life multicenter retrospective study using the JIRcohorte database. Joint Bone Spine. 2019; 86(3): 343-350. PubMed Abstract | Publisher Full Text

55. Turnier JL, Brunner $\mathrm{HI}$ : Tocilizumab for treating juvenile idiopathic arthritis. Expert Opin Biol Ther. 2016; 16(4): 559-66. PubMed Abstract | Publisher Full Text

56. Hara R, Umebayashi H, Takei S, et al.: Intravenous abatacept in Japanese patients with polyarticular-course juvenile idiopathic arthritis: Results from a phase III open-label study. Pediatr Rheumatol Online J. 2019; 17(1): 17. PubMed Abstract | Publisher Full Text | Free Full Text | Faculty Opinions Recommendation

57. Brunner HI, Tzaribachev N, Cornejo GV, et al:: Maintenance of antibody response to diphtheria/tetanus vaccine in patients aged 2-5 years with polyarticular-course juvenile idiopathic arthritis receiving subcutaneous abatacept. Pediatr Rheumatol Online J. 2020; 18(1): 19. PubMed Abstract | Publisher Full Text | Free Full Text | Faculty Opinions Recommendation

58. Ruperto N, Brunner HI, Zuber Z, et al.: Pharmacokinetic and safety profile of tofacitinib in children with polyarticular course juvenile idiopathic arthritis: Results of a phase 1, open-label, multicenter study. Pediatr Rheumatol Online J. 2017; 15(1): 86

PubMed Abstract | Publisher Full Text | Free Full Text

59. Kaegi C, Wuest B, Schreiner J, et al.: Systematic Review of Safety and Efficacy of Rituximab in Treating Immune-Mediated Disorders. Front Immunol. 2019; 10: 1990.

PubMed Abstract | Publisher Full Text | Free Full Text |

Faculty Opinions Recommendation

60. Kearsley-Fleet L, Sampath S, McCann LJ, et al.: Use and effectiveness of rituximab in children and young people with juvenile idiopathic arthritis in a cohort study in the United Kingdom. Rheumatology (Oxford). 2019; 58(2): 331-335.

PubMed Abstract | Publisher Full Text | Free Full Text

61. Arepalli S, Rosenbaum JT: The use of biologics for uveitis associated with spondyloarthritis. Curr Opin Rheumatol. 2019; 31(4): 349-354. PubMed Abstract | Publisher Full Text

62. Arnstad ED, Rypdal V, Peltoniemi S, et al.: Early Self-Reported Pain in Juvenile Idiopathic Arthritis as Related to Long-Term Outcomes: Results From the Nordic Juvenile Idiopathic Arthritis Cohort Study. Arthritis Care Res (Hoboken). 2019; 71(7): 961-969. PubMed Abstract | Publisher Full Text | Faculty Opinions Recommendation

63. Henrey A, Rypdal V, Rypdal M, et al.: Validation of prediction models of severe disease course and non-achievement of remission in juvenile idiopathic arthritis part 2: Results of the Nordic model in the Canadian cohort. Arthritis Res Ther. 2020; 22(1): 10.

PubMed Abstract | Publisher Full Text | Free Full Text | Faculty Opinions Recommendation

64. Brunner HI, Ruperto N, Tzaribachev N, et al:: Subcutaneous golimumab for children with active polyarticular-course juvenile idiopathic arthritis: Results of a multicentre, double-blind, randomised-withdrawal trial. Ann Rheum Dis. 2018; 77(1): 21-29.

PubMed Abstract | Publisher Full Text | Free Full Text

65. Stoll $\mathrm{ML}$, Cron $\mathrm{RQ}$ : Treatment of juvenile idiopathic arthritis: $\mathbf{A}$ revolution in care. Pediatr Rheumatol Online J. 2014; 12: 13.

PubMed Abstract | Publisher Full Text | Free Full Text

66. Brunner HI, Schanberg LE, Kimura Y, et al:: New Medications Are Needed for Children With Juvenile Idiopathic Arthritis. Arthritis Rheumatol. 2020; 72(11): 1945-1951.

PubMed Abstract | Publisher Full Text | Free Full Text
67. Skeie MS, Gil EG, Cetrelli L, et al:: Oral health in children and adolescents with juvenile idiopathic arthritis - a systematic review and meta-analysis. BMC Oral Health. 2019; 19(1): 285.

PubMed Abstract | Publisher Full Text | Free Full Text

68. Carlsson $\mathrm{AD}$, Wahlund $\mathrm{K}$, Kindgren $\mathrm{E}$, et al:: Orofacial pain in juvenile idiopathic arthritis is associated with stress as well as psychosocial and functional limitations. Pediatr Rheumatol Online J. 2019; 17(1): 83. PubMed Abstract | Publisher Full Text | Free Full Text

69. Isola G, Perillo L, Migliorati M, et al.: The impact of temporomandibular joint arthritis on functional disability and global health in patients with juvenile idiopathic arthritis. Eur J Orthod. 2019; 41(2): 117-124. PubMed Abstract | Publisher Full Text | Faculty Opinions Recommendation

70. Clerup M, Rypdal V, Arnstad ED, et al:: Long-Term Outcomes in Juvenile Idiopathic Arthritis: Eighteen Years of Follow-Up in the Population-Based Nordic Juvenile Idiopathic Arthritis Cohort. Arthritis Care Res (Hoboken). 2020 72(4): 507-516.

PubMed Abstract | Publisher Full Text | Faculty Opinions Recommendation

71. Stoustrup P, Glerup M, Bilgrau AE, et al.: Cumulative Incidence of Orofacial Manifestations in Early Juvenile Idiopathic Arthritis: A Regional, Three-Year Cohort Study. Arthritis Care Res (Hoboken). 2020; 72(7): 907-916.

PubMed Abstract | Publisher Full Text | Faculty Opinions Recommendation

72. Rongo R, Alstergren $\mathrm{P}$, Ammendola $\mathrm{L}$, et al:: Temporomandibular joint damage in juvenile idiopathic arthritis: Diagnostic validity of diagnostic criteria for temporomandibular disorders. J Oral Rehabil. 2019; 46(5): 450-459. PubMed Abstract | Publisher Full Text

73. Ma GMY, Calabrese CE, Donohue T, et al.: Imaging of the Temporomandibular Joint in Juvenile Idiopathic Arthritis: How Does Quantitative Compare to Semiquantitative MRI Scoring? J Oral Maxillofac Surg. 2019; 77(5): 951-958. PubMed Abstract | Publisher Full Text

74. Hsieh YJ, Darvann TA, Hermann NV, et al:: Three-dimensional assessment of facial morphology in children and adolescents with juvenile idiopathic arthritis and moderate to severe TMJ involvement using 3D surface scans. Clin Oral Investig. 2020; 24(2): 799-807.

PubMed Abstract | Publisher Full Text

75. Bernini JM, Kellenberger CJ, Eichenberger M, et al:: Quantitative analysis of facial asymmetry based on three-dimensional photography: A valuable indicator for asymmetrical temporomandibular joint affection in juvenile idiopathic arthritis patients? Pediatr Rheumatol Online J. 2020; 18(1): 10. PubMed Abstract | Publisher Full Text | Free Full Text

76. Leschied JR, Smith EA, Baker S, et al:: Contrast-enhanced MRI compared to direct joint visualization at arthroscopy in pediatric patients with suspected temporomandibular joint synovitis. Pediatr Radiol. 2019; 49(2): 196-202. PubMed Abstract | Publisher Full Text

77. Buch K, Peacock ZS, Resnick CM, et al.: Regional differences in temporomandibular joint inflammation in patients with juvenile idiopathic arthritis: A dynamic post-contrast magnetic resonance imaging study. Int $J$ Oral Maxillofac Surg. 2020; 49(9): 1210-6.

PubMed Abstract | Publisher Full Text | Faculty Opinions Recommendation

78. Resnick CM, Frid P, Norholt SE, et al:: An Algorithm for Management of Dentofacial Deformity Resulting From Juvenile Idiopathic Arthritis: Results of a Multinational Consensus Conference. J Oral Maxillofac Surg. 2019; 77(6): 1152.e1-1152.e33.

PubMed Abstract | Publisher Full Text

79. Stoustrup P, Resnick CM, Pedersen TK, et al:: Standardizing Terminology and Assessment for Orofacial Conditions in Juvenile Idiopathic Arthritis: International, Multidisciplinary Consensus-based Recommendations. $J$ Rheumatol. 2019; 46(5): 518-522. PubMed Abstract | Publisher Full Text

80. Stoustrup P, Herlin T, Spiegel L, et al.: Standardizing the Clinical Orofacial Examination in Juvenile Idiopathic Arthritis: An Interdisciplinary, Consensusbased, Short Screening Protocol. J Rheumatol. 2020; 47(9): 1397-404. PubMed Abstract | Publisher Full Text | Faculty Opinions Recommendation

81. Frid $\mathrm{P}$, Resnick $\mathrm{C}$, Abramowicz $\mathrm{S}$, et al.: Surgical correction of dentofacial deformities in juvenile idiopathic arthritis: A systematic literature review. Int $J$ Oral Maxillofac Surg. 2019; 48(8): 1032-1042.

PubMed Abstract | Publisher Full Text

82. Stoll $\mathrm{ML}, \mathrm{Kau} \mathrm{CH}$, Waite $\mathrm{PD}$, et al.: Temporomandibular joint arthritis in juvenile idiopathic arthritis, now what? Pediatr Rheumatol Online J. 2018; 16(1): 32. PubMed Abstract | Publisher Full Text | Free Full Text

83. Bollhalder A, Patcas R, Eichenberger M, et al.: Magnetic Resonance Imaging Followup of Temporomandibular Joint Inflammation, Deformation, and Mandibular Growth in Juvenile Idiopathic Arthritis Patients Receiving Systemic Treatment. J Rheumatol. 2020; 47(6): 909-916. PubMed Abstract | Publisher Full Text

84. British Society for Paediatric and Adolescent Rheumatology, The Royal College of Ophthalmologists: Guidelines for screening for Uveitis in Juvenile Idiopathic Arthritis (JIA) produced jointly by BSPAR and the RCOphth 2006. Reference Source

85. Angeles-Han ST, Ringold S, Beukelman T, et al:: 2019 American College of Rheumatology/Arthritis Foundation Guideline for the Screening, Monitoring, and Treatment of Juvenile Idiopathic Arthritis-Associated Uveitis. Arthritis Care 
Res (Hoboken). 2019; 71(6): 703-716.

PubMed Abstract | Publisher Full Text | Free Full Text |

Faculty Opinions Recommendation

86. Ramanan AV, Dick AD, Jones AP, et al.: Adalimumab plus Methotrexate fo Uveitis in Juvenile Idiopathic Arthritis. N Engl J Med. 2017; 376(17): 1637-1646. PubMed Abstract | Publisher Full Text

87. Allegra M, Gicchino MF, Giancane G, et al:: The Effect of Morning Stiffness Duration on the Definition of Clinically Inactive Disease in Juvenile Idiopathic Arthritis. J Rheumatol. 2020; 47(8): 1238-1241. PubMed Abstract | Publisher Full Text

88. Halyabar O, Mehta J, Ringold S, et al:: Treatment Withdrawal Following Remission in Juvenile Idiopathic Arthritis: A Systematic Review of the Literature. Paediatr Drugs. 2019; 21(6): 469-492. PubMed Abstract | Publisher Full Text | Free Full Text

89. Leong JY, Chen $\mathrm{P}, \mathrm{Yeo} J \mathrm{JG}$, et al.: Immunome perturbation is present in patients with juvenile idiopathic arthritis who are in remission and will relapse upon anti-TNF $\alpha$ withdrawal. Ann Rheum Dis. 2019; 78(12): 1712-1721. PubMed Abstract | Publisher Full Text | Free Full Text

90. Nieto-González JC, Rodríguez A, Gámir-Gámir ML, et al.: Can ultrasounddetected subclinical synovitis be an indicator of flare recurrence in juvenile idiopathic arthritis remission patients on tapered TNFi? Clin Exp Rheumatol. 2019; 37(4): 705-712. PubMed Abstract

91. Shoop-Worrall SJW, Wu Q, Davies R, et al: Predicting disease outcomes in juvenile idiopathic arthritis: Challenges, evidence, and new directions. Lancet Child Adolesc Health. 2019; 3(10): 725-733. PubMed Abstract | Publisher Full Text

92. Guzman J, Henrey A, Loughin T, et al:: Predicting Which Children with Juvenile Idiopathic Arthritis Will Not Attain Early Remission with Conventional Treatment: Results from the ReACCh-Out Cohort. J Rheumatol. 2019; 46(6): 628-635.

PubMed Abstract | Publisher Full Text | Faculty Opinions Recommendation

93. Guzman J, Oen K, Loughin T: Predicting disease severity and remission in juvenile idiopathic arthritis: Are we getting closer? Curr Opin Rheumatol. 2019; 31(5): 436-449.

PubMed Abstract | Publisher Full Text

94. Shoop-Worrall SJW, Hyrich KL: Predicting Remission Remains a Challenge in
Patients with Juvenile Idiopathic Arthritis. J Rheumatol. 2019; 46(6): 552-554. PubMed Abstract | Publisher Full Text

95. Rypdal V, Guzman J, Henrey A, et al:: Validation of prediction models of severe disease course and non-achievement of remission in juvenile idiopathic arthritis: Part 1-results of the Canadian model in the Nordic cohort. Arthritis Res Ther. 2019; 21(1): 270 .

PubMed Abstract | Publisher Full Text | Free Full Text

96. Giani T, de Masi S, Maccora I, et al:: The Influence of Overweight and Obesity on Treatment Response in Juvenile Idiopathic Arthritis. Front Pharmacol. 2019; 10: 637.

PubMed Abstract | Publisher Full Text | Free Full Text

97. Glerup M, Herlin T, Twilt M: Clinical Outcome and Long-term Remission in JIA Curr Rheumatol Rep. 2017; 19(12): 75.

PubMed Abstract | Publisher Full Text

98. Horton DB, Salas J, Wec A, et al.: Making Decisions About Stopping Medicines for Well-Controlled Juvenile Idiopathic Arthritis: A Mixed-Methods Study of Patients and Caregivers. Arthritis Care Res (Hoboken). 2019. PubMed Abstract | Publisher Full Text | Free Full Text

99. Minden K, Horneff G, Niewerth M, et al:: Time of Disease-Modifying Antirheumatic Drug Start in Juvenile Idiopathic Arthritis and the Likelihood of a Drug-Free Remission in Young Adulthood. Arthritis Care Res (Hoboken). 2019; 71(4): 471-481.

PubMed Abstract | Publisher Full Text | Faculty Opinions Recommendation

100. Ravelli A, Consolaro A, Horneff G, et al.: Treating juvenile idiopathic arthritis to target: Recommendations of an international task force. Ann Rheum Dis. 2018; 77(6): 819-828.

PubMed Abstract | Publisher Full Text

101. Hissink Muller P, Brinkman DMC, Schonenberg-Meinema D, et al:: Treat to target (drug-free) inactive disease in DMARD-naive juvenile idiopathic arthritis: 24-month clinical outcomes of a three-armed randomised trial. Ann Rheum Dis. 2019; 78(1): 51-59.

PubMed Abstract | Publisher Full Text | Faculty Opinions Recommendation

102. Swart JF, van Dijkhuizen EHP, Wulffraat NM, et al.: Clinical Juvenile Arthritis Disease Activity Score proves to be a useful tool in treat-to-target therapy in juvenile idiopathic arthritis. Ann Rheum Dis. 2018; 77(3): 336-342. PubMed Abstract | Publisher Full Text | Free Full Text 